reported hardly form a scientific justification for the statement, "There is therefore no basis for the preference shown for free range eggs".

$$
\text { Yours faithfully, }
$$

$$
\text { L. C. WALters }
$$

134 Park Road,

Chandlersford,

Hampshire.

These two letters refer to an article "Point of Distinction between Battery and Free Range Eggs" by Dennis Jones (Nature, 220, 921; 1968).

\section{New Materials make their Mark}

SrR,-The following comments are relevant to the letter "New Materials make their Mark"1.

It seems that we have now established that several groups contributed to the refining of the art of pyrolysis of textile fibre to carbon fibre that enabled the achievement of current high specific mechanical property figures.

As a participant on one of the groups involved, I can affirm that we had no knowledge of the methods used by Mr Watt and Mr Johnson until July 12, 1966. At this time, after we had submitted our paper for publication ${ }^{2}$, we received a note from one of our colleagues outlining his interpretation of the methods used by the Royal Aircraft Establishment. This note was based on a meeting between our colleague and Mr Watt and Mr Johnson on July 8, 1966.

The methods of Mr Prescott and myself, based on our original, entirely independent research, do not necessitate mechanical restraint of the textile fibre at any stage of the process.

Our patents ${ }^{3-5}$ are consequently independent of those granted to Mr Watt and Mr Johnson.

\section{Yours faithfully,}

EdWARD STANDAGE

Research Institute,

University of Dayton,

Dayton, Ohio.

'Watt, W., and Johnson, W., Nature, 220, 835 (1068).

2 Standage, A. E., and Prescott, R., Nature, 211, 169 (1966).

Belgian Patent No. 678,679.

"French Patent No. 1,471,993.

${ }^{6}$ Canadian Patent No. 790,509 (Priority date April 6, 1965).

Erratum. In the communication "Evidence for Order in the Structure of $\alpha$-Elastin" by M. Mammi et al. (Nature, 220,$371 ; 1968$ ) the last sentence of the fifth paragraph should read as follows: "The extended $\beta$-structure should be ruled out because it would show ${ }^{13,14}$ strong amide $I$ and II bands at about 1,630 and $1,530 \mathrm{~cm}^{-1}$. This conclusion is supported by the absence of bands in the 1,685 to $1,700 \mathrm{~cm}^{-1}$ region".

ERratum. In the article "Implications of Shock Effects in Iron Meteorites" by Anant V. Jain and Michael E. Lipschutz (Nature, 220, 139; 1968) the second sentence of the tenth paragraph should read "The matrix of the unshocked meteorite seems somewhat altered (Fig. 2a) as noted previously ${ }^{10 "}$.

Erratum. In the communication "Short Caesium Half-times in Patients with Muscular Dystrophy" by Ray D. Lloyd et al. (Nature, 220, 1029; 1968) the fifth sentence of the seventh paragraph on page 1030 should read "(EC) and (EP) are sisters, and (EC) has had more than one dystrophic child".

ERRATUM. In the article "Metabolic Approach to interpreting Animal Exploratory Activity" by Henry McIlwain (Nature, 220,$889 ; 1968$ ) the first sentence under the heading "Proposed Mechanism" on page 889 should read "Mechanisms interpreting change in EA in terms of depletion and competing metabolic processes ....".

\section{International Meetings}

January 6-8, Sonically Induced Vibration of Structures, Liverpool (Mr M. J. Crocker, University of Liverpool, Department of Building Science, Liverpool, UK).

May 6, Crop Protection, Ghent (Professor R. H. Kips, International Symposium on Crop Protection, Rijksfaculteit, Der Landbouwwetenschappen, Coupure Links 235, Ghent, Belgium).

June 9-13, Clean Air Congress and Exhibition, Dusseldorf (Verein Deutscher Ingenieure, Postfach 1139 4 Dusseldorf 1, Germany).

June 9-13, Air Pollution Problems, Dusseldorf (Kommission Reinhaltung der Luft, Verein Deutscher Ingenieure, Postfach 1139, Graf-Recke-Str. 84, 4 Dusseldorf 1, Germany).

June 10-12, Non-Destructive Testing of Concrete and Timber, London (The Institution of Civil Engineers, Great George Street, London SW1).

June 10-20, Marine and Shipping Conference, London (Institute of Marine Engineers, 76 Mark Lane, London EC3).

June 15-20, Data Processing, Montreal (Mrs Margaret Rafferty, Data Process Managing Association, 505 Busse Highway, Park Ridge, Illinois 60068, USA).

June 16-19, American Nuclear Society meeting, Seattle (Octave J. du Temple, 244 East Ogden Avenue, Hinsdale, Illinois 60521, USA).

June 16-21, Automatic Control, Warsaw (Organizing Committee, Ul Czackiego 3/5, POB 903, Warsaw 1 , Poland).

June 22-23, Application of Mathematics in Engineering, Weimar (Professor H. Matzke, Weimar College of Architecture and Building, Karl-Marx-Platz 2, 53 Weimar, Germany).

June 22-23, Nephrology, Stockholm (Dr F. Berglund, Postfach 272, Stockholm 1, Sweden).

June 23-25, Shock Tubes, Toronto (Professor I. I. Glass, Institute of Aerospace Studies, University of Toronto, Toronto 5, Canada).

June 23-28, Food Congress and Exhibition, Madrid (Llosent Maranon, c/o Federacion Nacional de Almacenistas de Alimentacion, Paseo del Prado 18-20, Planta LI, Madrid, Spain).

June 24-28, Aerosol Congress, Nice (Secretariat, Federation of European Aerosol Associations, Waisenhausstr. 2, Zurich 1, Switzerland).

June 30-July 3, Computer Technology, Manchester (Conference Department, Institution of Electrical Engineers, Savoy Place, London WC2).

July 1-5, Physiological Sciences, Belo Horizonte (Professor W. T. Beraldo, University Federal of Minas Gerais, c/o School of Medicine, Belo Horizonte, Minas Gerais, Brazil).

July 2-4, Goncrete Pavements, Paris (European Cement Association, 2 rue St Charles, Paris 15, France).

July 2-10, Protozoology, Leningrad (Dr I. B. Raikov, c/o Institute of Cytology, 32 Pr Malinka, Leningrad F-21, USSR).

July 7-11, Structure and Properties of Solid Surfaces, Paris (Professor J. Benard, Ecole Nationale Superieure de Chimie, 11 rue Pierre-Curie, Paris 5, France).

July 7-12, European Orthodontic Society, Edinburgh (Dr W. Russel Logan, 8 Chester Street, Edinburgh 3, Scotland). 